\title{
SURFICIAL BIOTURBATION AND RAPID BENTHIC REMINERALIZATION IN THE CAPE HATTERAS SHELF/SLOPE REGION
}

Final Report

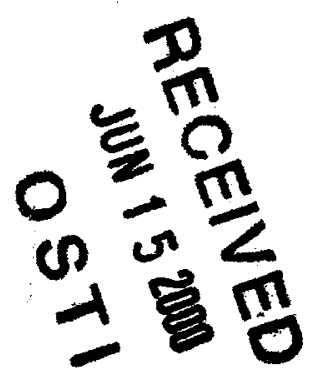

Robert C. Aller, Josephine Y. Aller, C. Lee, and J. Kirk Cochran

Marine Sciences Research Center

SUNY at Stony Brook

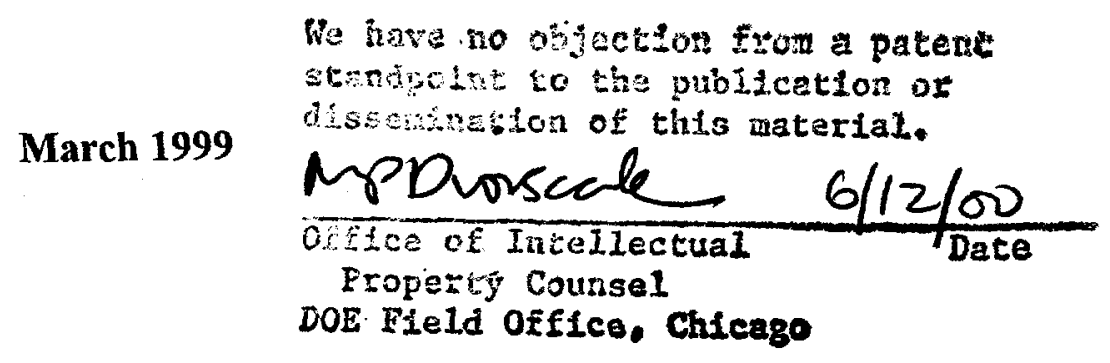

Prepared for

THE U.S. DEPARTMENT OF ENERGY

AWARD NO. DE-FG02-92ER61464 


\section{DISCLAIMER}

This report was prepared as an account of work sponsored by an agency of the United States Government. Neither the United States Government nor any agency thereof, nor any of their employees, make any warranty, express or implied, or assumes any legal liability or responsibility for the accuracy, completeness, or usefulness of any information, apparatus, product, or process disclosed, or represents that its use would not infringe privately owned rights. Reference herein to any specific commercial product, process, or service by trade name, trademark, manufacturer, or otherwise does not necessarily constitute or imply its endorsement, recommendation, or favoring by the United States Government or any agency thereof. The views and opinions of authors expressed herein do not necessarily state or reflect those of the United States Government or any agency thereof. 


\section{DISCLAIMER}

Portions of this document may be illegible in electronic image products. Images are produced from the best available original document. 
This is a final report for the DOE of grant DE-FG02-92ER61464 "Surficial bioturbation and rapid benthic remineralization in the Cape Hatteras shelf/ slope region". Over the past 6 years we have participated in a multidisciplinary field study called the Ocean margins Program (OMP) to examine the importance of continental margins in the global carbon cycle. Specifically, we have focused on the southern portion of the MidAtlantic Bight between Cape Hatteras and Chesapeake Bay where a large flux of freshwater and organic carbon enters the North Atlantic Ocean. Additionally, during the first stage of this project, we developed the use of Chl-a distributions in sediments as a quantitative indicator of benthic $\mathrm{C}$ flux and remineralization rates.

The primary objective of our research group has been to understand mechanisms and quantify biogeochemical processes in the seabed that affect cycling, flux, and storage of carbon on the ocean margin of the Mid-Atlantic Bight. The seafloor has a central role in the cycling of carbon and other reactive biogenic material in continental shelf/slope regions. Bottom deposits act both as sites of dynamic processing of organic debris and rapid interchange with overlying water, as well as relatively permanent repositories and integrative records of past or present elemental cycling patterns. Significant percentages of total water column primary production are typically remineralized on the bottom at continental shelf depths $(\sim 20-30 \%)$, and, over sandy regions, a substantial proportion of total primary production may be benthic in origin $(\sim 50 \%)$ (Jahnke, et al., 1996; Alongi, 1998 ). In the case of the east coast of North America, the existence of a carbon-rich (1$2 \%$ C) band of sediment stretching along slope between $\sim 1-2 \mathrm{~km}$ water depth implies possible extensive export of shelf-derived biogenic material and storage in slope depocenters (e.g. Walsh, et al., 1985). Understanding processes that might originate and maintain such a sedimentary feature was a major impetus for examining shelf - slope interactions at Cape Hatteras during OMP. We expect that our data and insights will help provide a direct estimate of net carbon export from the shelf to the slope, spatial patterns of export, and processes controlling remineralization, and sequestration at the land/ocean interface.

The initial phase of our study of benthic remineralization rates and associated infaunal community activities in the Cape Hatteras Shelf region, involved participation in a cruise from August 23 to Sept. 1, 1994 to the shelf break - upper slope region. A HAPS corer unit was used to remotely retrieve 4 relatively undisturbed cores from along the shelf-break within the coarse sand - mud transition zone in $\sim 50-200 \mathrm{~m}$ water depths, $35.40-35.35 \mathrm{~N}$ (north of slope sampling area). Because of the extremely complex terrain of the slope region (Manteo 467 Lease Block), the submersible DSV Johnson Sea Link was employed as the primary sampling vehicle to obtain cores which could be oriented relative to specific topographic high or low features. Slope stations located in mud deposits between $\sim 600$ - 900-m depth, were situated on ridges, within canyon valleys, or on near-vertical valley walls. The cruise was in conjunction with $\mathrm{L}$. $\mathrm{K}$. Benninger and $\mathrm{R}$. Jahnke (PI's who initiated and obtained NURP/DOE support for cruise). 
As previously reported for this region, numerous indicators demonstrate intense benthic recycling processes. Deposits were extensively bioturbated and permeated by a range of burrow and tube structures, including complex interconnected galleries formed by crustaceans. Excess ${ }^{234} \mathrm{Th}$ profiles in both slope and shelf-break deposits demonstrated substantial sediment-water particle fluxes and rapid penetration of material into the seafloor during bioturbation. Surfacemost values ranged from $\sim 10-45 \mathrm{dpm} \mathrm{g}^{-1}(0-0.5 \mathrm{~cm})$ and typical penetration to $>5 \mathrm{~cm}$ (slope sties: $\mathrm{D}_{\mathrm{B}} \sim 32 \pm 31 \mathrm{~cm}^{2} \mathrm{yr}^{-1}$, range 1.3-86; shelf break sites: $D_{B} \sim 11 \pm 6.8 \mathrm{~cm}^{2} \mathrm{yr}^{-1}$; range 4-20). The lowest particle mixing rates are apparently along valley walls. These values are in agreement with more southerly sites (DeMaster et al., 1994).

Utilizing our previously developed Chl-a distribution assay, we discovered that the Chl-a/phaeophytin ratio was higher at shelf break than slope sites indicating input of more degraded debris at deeper sites. All sites, however, were found to receive abundant inputs of labile planktonic material. Slope pore water profiles demonstrated degradation of fresh debris with $\mathrm{C} / \mathrm{N}$ regeneration ratios of $\sim 6.0$ (pore water profiles) to $\sim 4.5$ (sediment incubations), in contrast to bulk solid $\mathrm{C} / \mathrm{N}$ ratios of $\sim 9.5$. At slope sites, oxygen penetrated only $\sim 2-4 \mathrm{~mm}$ into surface sediment away from burrow structures, indicative of rapid decomposition and a dominance of anaerobic decomposition pathways. Short term incubations of slope sediments at in situ temperatures showed relatively high production of $\Sigma \mathrm{CO}_{2}$ in the upper $0-5 \mathrm{~cm}$ ranging from $\sim 0.66-6.8 \mathrm{mmol} \mathrm{m}^{-2} \mathrm{~d}^{-1}$ (mean = $4.2 \pm 2.1 \mathrm{mmol} \mathrm{m}^{-2} \mathrm{~d}^{-1}$ ). These are in the range of labile-organic $C$ fluxes expected from decomposition models of benthic Chl-a inventories measured in the region, both in this and other studies (e.g. Cahoon et al., 1994). The production rates are capable of supporting benthic fluxes in the range of $\sim 1-7 \mathrm{mmole}^{-2} \mathrm{~d}^{-1}$. The valley wall site had the lowest remineralization rate. Ridges and valley floors had relatively high rates but were variable.

The $\mathrm{C} / \mathrm{N}$ stoichiometry of decomposing organic material was found to be substantially lower than bulk $\mathrm{C} / \mathrm{N}$ ratios ( $\sim 9.5)$, as indicated by transport models of pore water profiles and regeneration ratios in incubated sediments. While the lower $\mathrm{C} / \mathrm{N}$ ratios in incubated sediment may partially reflect entombment of infauna they largely reflect the presence of labile organic matter. Regeneration ratios are similar at all sites regardless of bulk $\mathrm{C}$ pools and reflect the breakdown of fresh planktonic debris rather than the larger pool of residual background material. $\mathrm{CaCO}_{3}$ concentrations relatively constant over the upper $10 \mathrm{~cm}$ ranged from $6-9 \%$ and were highest in walls, lowest in valleys. $\mathrm{C}_{\mathrm{org}}$ concentrations ranged from $0.17-0.3 \%$, higher in walls, lowest in valleys.

$\Sigma \mathrm{CO} 2$ production fluxes and microbial populations in the upper $0-5 \mathrm{~cm}$ were lowest in walls and relatively high, but variable along ridges and in valleys. Nematodes numerically dominated the fauna at ridge and valley sites, indicating extensive grazing pressure on bacterial decomposers. Polychaetes dominate in wall sediments. Most infauna are $<0.5>0.125 \mathrm{~mm}$ with most between 0.3 and $0.5 \mathrm{~mm}$ and least numerous in the upper $0-5 \mathrm{~cm}$ and $0-10 \mathrm{~cm}$ in walls and most numerous although variable, along ridges. In contrast, molluscan death assemblages (partially decalcified) were most abundant in wall surface sediments $(0-5 \mathrm{~cm})$, suggesting relatively recent burial. 
Decalcification of molluscs in death assemblages averaged $18 \%$ at valley and ridge sites and $23 \%$ in walls. Living molluscs dominated by bivalves were prevalent at ridge sites. Boring of bivalves by gastropods is minimal suggesting that megafauna may be primarily responsible for mortality from predation and implying a likely large export of benthic biomass during secondary production on the slope.

During July and August of 1966, we returned to the shelf and slope regions off Cape Hatteras and collected additional samples during two cruises. Sediment cores were obtained along three primary East-West transects (water depth $\sim 100-500 \mathrm{~m} ; 36^{\circ} 20^{\prime} \mathrm{N}, 35^{\circ}$ $50 \mathrm{~N}, 35^{\circ} 25^{\mathrm{N}} \mathrm{N}$ ) using several shipboard coring techniques (HAPS Corer, Box Corer, Multi-Corer). The data obtained during these cruises consistently demonstrated high reactive-particle flux (shelf export), and intense bioturbation and remineralization in this shelf break / upper slope region. Deposits were found to be inhabited by an abundant faunal community responsible for rapid rates of particle reworking and pore water irrigation. Fauna were numerically highly variable $\left(\sim 50-200\right.$ thousand $\mathrm{m}^{-2},>0.5 \mathrm{~mm}$ mesh) and dominated in box cores by polychaetes and large nematodes. We found little evidence of regular depth-dependent faunal abundances $(\sim 100-850 \mathrm{~m}$ depth), due possibly to complex topography, sedimentation patterns, and uniformly high delivery of fresh organic matter to the shelf and slope. Excess ${ }^{244} \mathrm{Th}\left(\mathrm{t}_{1 / 2}=24.1 \mathrm{~d}\right)$ was present at all stations, with surface values $(0-0.5 \mathrm{~cm})$ ranging from $\sim 13-50 \mathrm{dpm} \mathrm{g}^{-1}$ and typically penetrating to $>5-7 \mathrm{~cm}$. Values of $\mathrm{D}_{\mathrm{B}}$ estimated using excess ${ }^{234} \mathrm{Th}$, ranged from $\sim 4-50 \mathrm{~cm}$ ${ }^{2} \mathrm{yr}^{-1}$. $\mathrm{Br}^{-}$tracer penetrated up to $\sim 7-10 \mathrm{~cm}$ into shipboard-incubated sediment cores in $<1$ day at some sites. Chl- $a$ and phaeophytin distributions in sediments indicated high and recent input of fresh planktonic debris. Chl-a/phaeophytin ratios were smaller at shallower stations implying that more degraded planktonic debris is reaching the seafloor at those sites. Sediment incubation experiments at in situ temperatures showed $\mathrm{C} / \mathrm{N}$ production ratios $<6$, consistent with remineralization of recently formed organic matter. $\Sigma \mathrm{CO}_{2}$ and $\mathrm{NH}_{4}^{+}$production fluxes (0-10 cm depth interval) ranged from 11-24 and 1-8 mmol m-2 $\mathrm{d}^{-1}$ with average rates of $\sim 18$ and $\sim 4 \mathrm{mmol} \mathrm{m}^{-2} \mathrm{~d}^{-1}$, respectively, and do not appear to vary systematically with depth (or temperature). Diffusive $\mathrm{O}_{2}$ fluxes measured in shipboard incubated cores averaged $\sim 14 \mathrm{mmol} \mathrm{m}^{-2} \mathrm{~d}^{-1}$ (range 7-26). Imbalances between $\mathrm{O}_{2}$ flux and $\Sigma \mathrm{CO}_{2}$ production $\left(\mathrm{O}_{2}\right.$ flux $<\Sigma \mathrm{CO}_{2}$ flux $)$ at some stations may be due to recent nonsteady state input (pulses) and downward mixing of fresh organic matter. Estimates of $\Sigma \mathrm{CO}_{2}$ production using excess $\mathrm{Chl}-a$ inventories and an assumed $\mathrm{Chl}-a / \mathrm{C}$ ratio predict $\Sigma \mathrm{CO}_{2}$ fluxes in good agreement with estimates from sediment incubations. The results of the 1994 and 1996 cruises are similar and are consistent with extremely high delivery of reactive fresh material, intense seafloor processing with rapid and significant off-shelf transport of reactive biogenic material, and extensive eventual burial of $\mathrm{C}$ in the Cape Hatteras region.

Our future objectives are to interact with other scientists comprising the benthic research group (listed below) and integrating our results from the shelf, shelf edge, upper slope, and lower slope areas in order to derive a consistent regional picture of carbon cycling and likely controlling processes. This interdisciplinary synthesis will be carried out under the umbrella of NSF's JGOFS program. Specifically we intend to 1) determine 
the magnitude, source, and patterns of reactive carbon deposition and remineralization rates at the seafloor in the shelf - slope region off Cape Hatteras; 2) quantify permanent burial rates of carbon and associated biogenic material, and 3) evaluate and model the major factors controlling observed remineralization rates and patterns of carbon storage at the seafloor. The results the synthesis by the benthic research group will be examined in conjunction with the findings of research groups who concentrated on water column processes, and will allow us to address the overall OMP hypothesis that significant offshelf export of reactive organic carbon occurs in the Cape Hatteras region.

Benthic research group: L. Benninger, I. Suayah (UNC - Chapel Hill), sediment radiochemistry (210-Pb, $\mathrm{Pu}, 14-\mathrm{C})$, sediment reworking, $\mathrm{C}$ burial on the shelf, shelf edge and upper slope; R. Jahnke (SkIO), benthic solute exchange on the shelf and lower slope; C. Martens, M. Alperin, D. Alberts (UNC - Chapel Hill), remineralization, DOC, S cycle, C burial, in situ tracers on upper and lower slope; D. DeMaster, N. Blair, C. Thomas (NCSU), $C$ isotopes in sediment and fauna, radiochemistry, solute exchange, remineralization, $\mathrm{C}$ burial, bioturbation, in situ tracers on upper and lower slope; $\mathbf{R}$. Aller, J. Aller, K. Cochran, C. Lee (SUNY - Stony Brook), Green M. (St. Joseph's College, Maine), surficial diagenesis, 234-Th, molecular biomarkers, benthic communities, bioturbation remineralization rates on shelf edge, and upper slope; $L$. Mayer (U. Maine), organic matter - mineral associations on shelf and slope; C. Reimers, S. Boehme (Rutgers), microelectrode studies; P. Santschi (TAMUG), boundary layer colloids on shelf and slope

\section{Publications to date resulting from OMP project:}

Green, M.A. 1996. The biogeochemical mechanisms driving calcite and aragonite saturation states in long Island Sound sediments: the effects on juvenile bivalves, benthic foraminifera, and carbonate debris preservation. $\mathrm{Ph}$.D. Dissertation, State University of New York, Stony Brook, $257 \mathrm{pp}$.

Hanguo, Wu, M.A. Green, and M.I. Scranton. 1997. Acetate cycling in the water column and surface sediment of Long Island Sound following a bloom. Limnol. \& Oceanogr. 43, $18-28$.

Gerino, M., R.C. Aller, C. Lee, J.K. Cochran, J.Y. Aller, M.A. Green, and D. Hirschberg. 1998. Comparison of different tracers and methods (in situ, laboratory) used to quantify bioturbation during a spring bloom: 234 Thorium, luminophores, and $\mathrm{Chl}$. A. Estuarine. Coastal Mar. Sci. 46, 531-547.

Green, M. A., R. C. Aller, and J. Y. Aller, 1998, The influence of carbonate dissolution on the survival of shell-bearing meiobenthos in nearshore sediments Limnol. Oceanogr. 43, 18-28.

Green, M.A. and R.C. Aller. 1998. Seasonal patterns of carbonate diagenesis in nearshore terrigenous muds: relation to spring phytoplankton bloom and temperature. J. Mar. Res. 56, 1097-1123.

Aller, R. C. and J. Y. Aller, 1998, The effect of biogenic irrigation intensity and solute exchange on diagenetic reaction rates in marine sediments. J. Mar. Res., 56, 905-936 
Aller, R. C., 1998, Solute transport and biogeochemical reactions in the bioturbated zone: structure and function. In: The benthic boundary layer: Transport processes and biogeochemistry. (B. Boudreau and B. B. Jørgensen, eds.). Oxford Press (in press).

Sun, Ming-Yi, S. G. Wakeham, R. C. Aller, and C. Lee, 1998, Impact of seasonal hypoxia on diagenesis of phytol and its derivatives in Long Island Sound. Marine Chem. 62, 157-173.

Hulth, S., R. C. Aller, and F. Gilbert, 1998, Coupled anoxic nitrification / manganese reduction in marine sediments. Geochim. Cosmochim. Acta. (in press).

Green, M.A. and R.C. Aller. 1999. Rapid, short-term changes in calcite and aragonite saturation states in Long Island Sound and the associated fluxes and dissolved $\mathrm{Ca}^{2+}$, $\mathrm{Mg}^{2+}, \mathrm{Sr}^{2+}$, and $\mathrm{F}^{-}$(in preparation).

Aller, J.Y., R.C. Aller, and M.A. Green. 1999. Benthic Community Distributions and Biogeochemical Cycling in the Cape Hatteras Shelf/Slope Region (in preparation)

Abstracts:

Green M. A., R. C. Aller, J. Y. Aller, C. Lee, and J. K. Cochran. 1997. Benthic remineralization, bioturbation, and biology of the Cape Hatteras shelf-break region OMP Meeting. Savannah, GA. January 1997.

Aller, J.Y. and R.C. Aller. 1998. Benthic Community Distributions and Biogeochemical Cycling in the Cape Hatteras Shelf/Slope Region. EOS, Transactions, AGU, 79(1) OS109.

Hulth, S., R.C. Aller and F. Gilbert. 1998. Anoxic Nitrification and Coupled NitrificationDenitrification in Anoxic Marine Sediments. 1998. EOS, Transactions, AGU, 79(1) OS95.

Ingalls, A.E., R.C. Aller, C. Lee and M.-Y, Sun. 1998. The Influence of Macrofauna Abundance on Chlorophyll-a Degradation in Coastal Marine Sediments. EOS, Transactions, AGU, 79(1) OS43.

Sun, M.-Y., R.C. Aller, C. Lee and S.G. Wakeham. 1998. A Microcosm Study to Test the Influences of Macrofauna Abundance of Degradation of ${ }^{13} \mathrm{C}$-labeled Algal Lipids in Surface Sediments. EOS, Transactions, AGU, 79(1) OS66. 